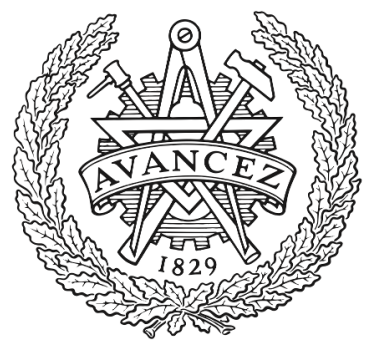

CHALMERS

UNIVERSITY OF TECHNOLOGY

\title{
Long-term frozen storage of wheat bread and dough - Effect of time, temperature and fibre on sensory quality, microstructure and state of water
}

Downloaded from: https://research.chalmers.se, 2023-04-26 13:49 UTC

Citation for the original published paper (version of record):

Eckardt, J., Ohgren, C., Alp, A. et al (2013). Long-term frozen storage of wheat bread and dough Effect of time, temperature and fibre on sensory quality, microstructure and state of water. Journal of Cereal Science, 57(1): 125-133. http://dx.doi.org/10.1016/j.jcs.2012.10.007

N.B. When citing this work, cite the original published paper. 


\title{
Long-term frozen storage of wheat bread and dough - Effect of time, temperature and fibre on sensory quality, microstructure and state of water
}

\author{
J. Eckardt ${ }^{\mathrm{a}, \mathrm{b}}$, C. Öhgren ${ }^{\mathrm{a}, *}$, A. Alp ${ }^{\mathrm{a}}, \mathrm{S}$. Ekman ${ }^{\mathrm{a}}$, A. Åström ${ }^{\mathrm{a}}, \mathrm{G}$. Chen ${ }^{\mathrm{c}}$, J. Swenson ${ }^{\mathrm{c}}$, D. Johansson ${ }^{\mathrm{a}, \mathrm{d}}$, \\ M. Langton ${ }^{\mathrm{a}, \mathrm{d}}$ \\ a SIK - The Swedish Institute for Food and Biotechnology, Box 5401, 40229 Göteborg, Sweden \\ ${ }^{\mathrm{b}}$ Department of Applied Chemistry, Chalmers University of Technology, Göteborg, Sweden \\ ${ }^{\mathrm{c}}$ Department of Applied Physics, Chalmers University of Technology, Göteborg, Sweden \\ d Department of Food Science, SLU - Swedish University of Agricultural Sciences, PO Box 7051, SE-756 45 Uppsala, Sweden
}

\section{A R T I C L E I N F O}

\section{Article history:}

Received 31 May 2012

Received in revised form

24 October 2012

Accepted 28 October 2012

\section{Keywords:}

Bread

Ice formation

Frozen storage

Temperature

\begin{abstract}
A B S T R A C T
The objective of this study was to determine effect of storage time, storage temperature and addition of fibre on sensory quality, state of water, microstructure and texture of bread and dough.

Samples with and without fibre, were stored frozen for 2, 3.5 and 6 months at temperatures of -19 , -16 and $-8{ }^{\circ} \mathrm{C}$ as dough and bread. Sensory quality was evaluated by a trained analytical panel. Microstructure was analysed by light microscopy. Texture measurements were performed on bread, and the state of water was measured by differential scanning calorimetry.

Bread without fibre stored as dough at $-19{ }^{\circ} \mathrm{C}$ was the sample most like freshly baked bread. Sensory evaluation also confirmed that quality of the final bread was improved if samples were stored as dough compared to stored as bread. The microstructure had larger gaps between the starch and gluten phases when stored at warmer temperatures, due to retrogradation of starch, dehydration of gluten and water migration. DSC measurements showed that bread stored at $-19^{\circ} \mathrm{C}$ gained extra amount of freezable water, but lost ice after storage at $-8{ }^{\circ} \mathrm{C}$. Texture measurements showed that firmness increased with extended storage time. Bread stored at $-8{ }^{\circ} \mathrm{C}$ had lowest quality in all measurements.
\end{abstract}

(c) 2012 Elsevier Ltd. All rights reserved.

\section{Introduction}

The staling or deterioration of bread has been known since ancient times and has kept researchers busy over several centuries. Still, parts of the mechanism remain unknown. Today the ageing of bread correlates with immense economic losses. It is not a deterioration caused by microorganisms but rather adverse changes in crumb and crust resulting in a poor taste, although the product might be only a few days old. Freezing has become a popular method to retard the staling rate and to extend shelf life. It allows suppliers to produce in larger amounts and with a greater variety. Often it is applied not only to unproofed dough, which is delivered to retailers and there proofed and baked, but also to semi-baked and fully baked bread, with the advantage that the retailer does not need special equipment for proofing. At the same time freezing also causes losses in quality. Several ingredients and additives, such

\footnotetext{
* Corresponding author. Department of Structure and Material Design, SIK - The Swedish Institute for Food and Biotechnology, Box 5401, SE-40229 Göteborg, Sweden. Tel.: +46 1051666 98, +46 7042056 30; fax: +46 (0) 31833782 .

E-mail address: Camilla.Ohgren@sik.se (C. Öhgren).
}

as emulsifiers and enzymes, are commonly used to reduce these adverse effects. Although prolonged storage times are commonly used by the industry, the effects of freezing itself or only short frozen storage times have often been the primary focus of researchers (Baier-Schenk et al., 2005; Bárcenas et al., 2003; Filipović et al., 2008; Hamdami et al., 2007; Lucas et al., 2005; Mandala et al., 2009; Neyreneuf and Delpuech, 1993; Zounis et al., 2002). Moreover, long storage seems to have a more harmful effect compared to the freezing process itself. Consumer acceptance is decreasing, in particular, when the crumb firmness rises, when the crust becomes softer and when the bread has a dry mouth feel. Fresh-baked bread typically has an attractive golden brown crust, a pleasant roasted aroma, good slicing characteristics, a soft and elastic crumb texture and a moist mouth feel (Selomulyo and Zhou, 2007).

When bread or dough is frozen, the major changes occurring are freeze-concentration of the aqueous solution and a great increase in viscosity until a mixed glassy-crystalline state is reached. That means that mainly water crystallises first, increasing the concentration of the surrounding solution. A higher concentration of solutions creates conditions in which reactions can increase in rate, 
osmotic pressure rises, solutes can crystallise and freezing point decreases. Due to the low temperature, proteins can denaturate because of hydrophobic interactions (Walstra, 2003). The higher the freezing rate the smaller the ice crystals and the lower the mechanical damage of the structure. Faster freezing rates also result in lower freeze-concentration effects, because less time is given to reach the equilibrium state. On the other hand, cooling rates that are too high can harm yeast cells in raw dough (Mazur, 1970). For unfermented dough it is sufficient to keep yeast cells as viable as possible, but Hsu et al. (1979) describe that, even when proofing frozen stored dough to the same volume, bread that was freeze-stored longer had less volume after baking. To explain this, the authors assume a relation to the release of enzymes and reducing agents from the content of dead and disrupted yeast cells. Other authors share this view (Inoue and Bushuk, 1992; Wolt and D'Appolonia, 1984). Therefore, an optimum freezing rate, depending on the ingredients, has to be found for the freezing of each type of raw dough.

The addition of fibre to dough is a subject of controversy in the literature. By adding different kinds of fibres, Filipović et al. (2008) found partly positive effects on the yeast activity in frozen doughs, in particular, for longer storage times. The authors also report a disruption in the gluten matrix and therefore a decrease in quality of dough and bread. Also possible is a different effect of soluble and insoluble fibres, but again in this area the literature is ambiguous. While Seetharaman et al. (1997) found a poor gluten development and extensive starch gelatinisation during baking when adding soluble fibres, Polaki et al. (2010) report that the gluten matrix was significantly developed and had a mean pore size similar to fresh samples. Leray et al. (2010) even found that the addition of soluble fibres to wheat dough prevents damage caused by freezing on dough rheology. For dough enriched with insoluble fibres Seetharaman et al. (1997) detected a better gluten structure; however, they also described a disrupted gluten network, caused by strands of insoluble fibres, leading to a collapse of air bubbles and a decreased shelf stability. Clearly, fibre in dough interacts with the gluten matrix. To what extent, which types of fibre and chain lengths, and whether it has mainly positive or negative effects on the quality needs to be further investigated.

The aim of this study was to determine the effect of storage time, storage temperature and addition of fibre on sensory quality, microstructure, texture and the state of water of bread and dough. The holistic analysis and the resulting conclusions on the changes during frozen storage make this study a unique work.

\section{Material and methods}

\subsection{Preparation of dough and frozen storage regimes}

Raw frozen dough samples, one type without fibre $(\mathrm{N})$ and the other type with fibre (Fi), both commercial, were provided by Lantmännen Unibake (Denmark) in boxes of 130 and 150 pieces per box, wrapped in plastic bags. A number of 10 boxes of each sample were provided. The pieces of raw dough weighed ca. $51 \mathrm{~g}(\mathrm{~N})$ resp. $68 \mathrm{~g}$ (Fi). Dough without fibre contained wheat flour, water, yeast, vegetable oil, sugar, skimmed milk powder, wheat gluten, iodised salt, stabilisers (E412, E466), dextrose, emulsifier (vegetable E472e), flour treatment agent (E300) and enzymes, while the dough with fibre consisted of wheat flour, water, wheat kernels, yeast, sugar, vegetable oil, skimmed milk powder, wheat gluten, iodised salt, stabilisers (E412, E466), dextrose, emulsifier (vegetable E472e), flour treatment agent (E300) and enzymes. All samples were frozen in the same way and transported to SIK Gothenburg at a temperature of $-20^{\circ} \mathrm{C}$. One part of the samples was subsequently baked, put into plastic bags of 9-12 pieces and closed with a staple. Those samples
(Be) were frozen at $-19^{\circ} \mathrm{C}$ in a walk-in freezer, which was located in a refrigerated room. Afterwards, the samples were divided into different freezers at temperatures of $-8^{\circ} \mathrm{C}$ (mean: $-8.2^{\circ} \mathrm{C} \pm 0.7^{\circ} \mathrm{C}$; $69.5 \% \mathrm{RH} \pm 5.5 \%),-16{ }^{\circ} \mathrm{C}$ (mean: $-16.1{ }^{\circ} \mathrm{C} \pm 1.4{ }^{\circ} \mathrm{C} ; 67.4 \% \mathrm{RH} \pm 7.5 \%$ ) and $-19{ }^{\circ} \mathrm{C}$ (mean: $-19.0^{\circ} \mathrm{C} \pm 0.6 ; 80.5 \% \mathrm{RH} \pm 6.5 \%$ ). The other part was kept as frozen dough, wrapped in plastic bags in cartons and divided into the different freezers with the stated temperatures. These dough samples were baked after each storage time before the analysis (Af). References ( $\mathrm{N}$ and Fi reference) were analysed at the initial point when they arrived at SIK Gothenburg and after 2, 3.5 and 6 months of frozen storage.

\subsection{Thawing, proofing and baking}

For baking the dough, samples were withdrawn from the freezer; 12 samples were put on one tray with baking paper and covered with plastic. They were thawed $75 \mathrm{~min}$ at ambient temperature $\left(21-23^{\circ} \mathrm{C}\right)$. Thereafter, they were put into a proofing chamber and proofed for $50 \mathrm{~min}$ at $35^{\circ} \mathrm{C}$ and $75 \% \mathrm{RH}$. Afterwards, the samples were baked for $10 \mathrm{~min}$ at $190{ }^{\circ} \mathrm{C}$ in an air oven. The trays were automatically rotated horizontally during the baking time. When only a few samples were baked, the oven was filled with additional dough pieces to simulate a full oven with equal baking conditions. After baking, all samples were taken off the tray, put on a wooden table and cooled for $1 \mathrm{~h}$ at room temperature and for another hour at a controlled temperature of $23{ }^{\circ} \mathrm{C}$ and $50 \% \mathrm{RH}$. For $\mathrm{N}$ and Fi the same procedure was used.

Frozen stored bread was thawed as follows: after each storage time, frozen stored bread was withdrawn from the freezer, taken out of the bag and thawed for $130 \mathrm{~min}$ at a controlled temperature of $24{ }^{\circ} \mathrm{C}$ and $50 \% \mathrm{RH}$. During thawing, the samples were lying on a tray and covered with plastic. Tests showed that the core temperature reached the ambient temperature after that time.

\subsection{Mass, volume and macroscopic investigation}

Two hours after baking, one vertical slice of approx. $2 \mathrm{~cm}$ thickness was cut out of the middle of each sample. The slices were scanned with an ordinary PC scanner. Frozen stored bread was thawed as stated above and scanned in the same way as fresh baked bread.

For mass investigations single samples were taken out of the plastic bag and weighed using a scale with $\pm 0.01 \mathrm{~g}$ precision. The samples were returned into the plastic bag and the box, and were thereafter put back into the freezer. The whole process took no longer than $3 \mathrm{~min}$. Baked samples were weighed approximately $1 \mathrm{~h}$ after baking, using the same scale as for the frozen samples. Bread baked before freezing was weighed by taking single samples out of the plastic bag.

The loaf volume was measured at ambient temperature approximately $1 \mathrm{~h}$ after baking, with at least four samples per recipe and temperature, by rapeseed displacement according to the AACC method 10-05 (AACC, 2001). Bread baked before storage was not measured again after thawing.

\subsection{Sensory evaluation}

After 2, 3.5 and 6 months of frozen storage the quality of bread was evaluated by an analytical sensory panel consisting of seven assessors, using quantitative descriptive analysis (QDA). Four training sessions were carried out in which the panel came to an agreement of 16 attributes characterising appearance, flavour, aroma and texture, see Table 1 . The evaluation was done in normal light conditions at room temperature. Samples were coded randomly with 3-digit numbers and served in two replicates. The 
Table 1

Sensory attributes and explanation including min and max scores reached in the sessions.

\begin{tabular}{|c|c|c|}
\hline Sensory attribute & Description & $\begin{array}{l}\text { Min and } \\
\max \text { score }\end{array}$ \\
\hline \multicolumn{3}{|l|}{ Appearance } \\
\hline Even shape & Degree of even shape (round/uneven) & $48.1 / 88.6$ \\
\hline Air bubbles & $\begin{array}{l}\text { Degree of spotted/speckled surface due to } \\
\text { air bubbles }\end{array}$ & $13.9 / 89.5$ \\
\hline Crumpled crust & Degree of crumpled/wrinkled surface & $2.5 / 58.4$ \\
\hline \multicolumn{3}{|l|}{ Odour } \\
\hline Total odour & Odour intensity, irrespective to the type & $54.2 / 87.3$ \\
\hline $\begin{array}{l}\text { Freshly baked } \\
\text { odour }\end{array}$ & Smell of fresh bread & $6.8 / 81.9$ \\
\hline Yeasty odour & Smell of yeast & $10.9 / 32.9$ \\
\hline Off-odour & $\begin{array}{l}\text { Smell of something other than characteristic } \\
\text { smell of bread }\end{array}$ & $5.8 / 83.4$ \\
\hline \multicolumn{3}{|l|}{ Flavour } \\
\hline Total flavour & Flavour intensity, irrespective to the type & $40.6 / 86.6$ \\
\hline Yeast flavour & Flavour of yeast & $7.1 / 38.0$ \\
\hline Off-flavour & $\begin{array}{l}\text { Taste of something other than characteristic } \\
\text { flavour of bread }\end{array}$ & $3.2 / 76.3$ \\
\hline \multicolumn{3}{|l|}{ Texture by finger } \\
\hline Cracking & $\begin{array}{l}\text { Amount of crust cracks when pressure } \\
\text { is applied }\end{array}$ & $11.3 / 58.6$ \\
\hline Springiness & $\begin{array}{l}\text { Degree of how fast the bun returns to its } \\
\text { shape after pressure }\end{array}$ & $16.6 / 82.6$ \\
\hline Compactness & $\begin{array}{l}\text { Degree of how airy or dense the bun is } \\
\text { when pressure is applied }\end{array}$ & $10.7 / 84.2$ \\
\hline Elasticity & $\begin{array}{l}\text { Degree of how elastic is the bun when it } \\
\text { is broken }\end{array}$ & $6.1 / 80.1$ \\
\hline \multicolumn{3}{|c|}{ Texture by mouth feel } \\
\hline Airy & $\begin{array}{l}\text { Degree of air in the bun, assessed after } \\
\text { first or second chew }\end{array}$ & $24.8 / 80.2$ \\
\hline Moist & $\begin{array}{l}\text { Degree of moisture in the bun, assessed } \\
\text { after chewing for } 5-10 \mathrm{~s}\end{array}$ & $13.3 / 83.6$ \\
\hline
\end{tabular}

attributes were appraised on a $100 \mathrm{~mm}$ continuous line scale, anchored $10 \mathrm{~mm}$ from each end with the terms slight and much. The data were collected with a computerised system (FIZZ 2.46 B) and statistically analysed.

\subsection{Texture analysis}

Texture analysis was performed according to a modified version of the AACC method 74-09 (AACC, 2001) using an Instron Universal Testing Machine 5542 (Instron, Norwood, MA, USA). For each sample three breads were used for texture measurements. Two vertical slices of $2 \mathrm{~cm}$ thickness were cut from each bread. A cylindrical metal probe of $20 \mathrm{~mm}$ diameter was pushed into the crumb in the middle of the slices with a constant speed of $1.7 \mathrm{~mm} / \mathrm{s}$. The compressive stress at $40 \%$ compression was used as a measure of the bread firmness. The measurements were performed either $2 \mathrm{~h}$ after baking or after thawing as described above.

\subsection{Light microscopy}

The light microscope Nikon Microphot-FXA (Japan) was used, to which an Altra 20 camera and a computer were connected. The samples were analysed using 4x,10x, 20x, 40x and 100x objectives.

The sample was prepared as follows: baked bread in cubes of approximately $2 \mathrm{~mm}^{3}$ was cut from the centre of the sample. The cubes were airfixed by lying on a grid above formalin and glutaraldehyde in $\mathrm{CaO}_{3}$ overnight. The next day they were placed above $2 \%$ $\mathrm{OsO}_{4}$ for $2.5 \mathrm{~h}$. In the case of raw dough samples in cubes of similar size were cut from the centre of the sample at $-8{ }^{\circ} \mathrm{C}$. They were airfixed at $-8{ }^{\circ} \mathrm{C}$ by lying on a grid above formalin and glutaraldehyde in $\mathrm{CaO}_{3}$ for $42 \mathrm{~h}$. Afterwards samples were placed above $2 \% \mathrm{OsO}_{4}$ in $20 \% \mathrm{NaCl}$ for $6 \mathrm{~h}$. In a graded series of ethanol solutions (50, 70, 90 and $99.5 \%$ by volume) both types of samples were dehydrated at room temperature and subsequently embedded in Technovit 7100. Sections of $1.0 \mu \mathrm{m}$ were cut with an RMC Power Tome XL using glass knives; the samples were subsequently placed on glass slides. The sections were stained with Lugol's iodine solution to visualise the starch phase and light green in acetic acid was used to visualise the protein phase as well as the yeast cells.

\subsection{State of water}

The state of crumb water was investigated with differential scanning calorimetry on DSC Q1000 (TA Instruments, DE, USA). For each type of dough and bread the samples were cut out of the central crumb and hermetically sealed in aluminium pans. An empty pan was used as reference and dry helium $(25 \mathrm{~mL} / \mathrm{min})$ was used as the purge gas. The cell constants and temperature calibration were carried out with indium, mercury and Millipore water. All crumb samples were measured by cooling at $10^{\circ} \mathrm{C} / \mathrm{min}$ from 20 to $-50^{\circ} \mathrm{C}$, holding at $-50{ }^{\circ} \mathrm{C}$ for $10 \mathrm{~min}$ and then heating at $10^{\circ} \mathrm{C} /$ min back to $20^{\circ} \mathrm{C}$. The amount of freezable water was calculated from the total endothermic enthalpy deduced by integrating the ice-melting peak.

\subsection{Statistical analysis}

Principal component analysis (PCA) and partial least squared regression were performed using the statistical programme SIMCA$\mathrm{P}+$ from Umetrics $\mathrm{AB}$ (Sweden) to evaluate the influence of the different effects on the characteristics. All values were normalised to allow the comparison between the different measuring techniques. Results that did not show a harmonic distribution were transformed to log scale.

\section{Results}

\subsection{Macroscopic investigation}

Fig. 1 shows $\mathrm{N}$ reference (Fig. 1a) compared to bread without fibre baked from frozen dough (NAf) stored for 6 months at $-19{ }^{\circ} \mathrm{C}$ (Fig. 1b) and $-8{ }^{\circ} \mathrm{C}$ (Fig. 1c), and bread without fibre baked before storage (NBe) stored at $-19{ }^{\circ} \mathrm{C}$ (Fig. 1d) and $-8{ }^{\circ} \mathrm{C}$ (Fig. 1e). Bread with fibre baked from frozen dough is named FiAf, and bread with fibre baked before storage is named FiBe. NAf shows a decrease in volume, in particular the storage at $-8{ }^{\circ} \mathrm{C}$. The volume of bread baked from frozen dough decreased significantly after 6 months compared to the references, with the exception of NAf stored at $-19{ }^{\circ} \mathrm{C}$.

In the reference the gas cells were very even distributed throughout the entire loaf. They had a similar size and a round shape, and not many big gas cells could be observed. Close to the crust gas cells tended to be smaller, and a more compact structure could be recognised. FiAf had more big gas cells than bread without fibre. After frozen storage as dough and subsequent baking, gas cells tended to fuse into bigger bubbles, as shown in Fig. 1b and c. The gas cells of NAf appeared to be more oval and ruptured in shape after frozen storage compared to FiAf, particularly for -16 and $-8{ }^{\circ} \mathrm{C}$. In FiAf, gas cells were more round than in bread without fibre. In NBe (Fig. 1d, e) the gas cell distribution is the same as the reference, since the bread was baked before storage, but a slight deformation on the bottom (Fig. 1e) and a crumpled crust, particularly at a storage at $-8^{\circ} \mathrm{C}$, characterised those samples. 

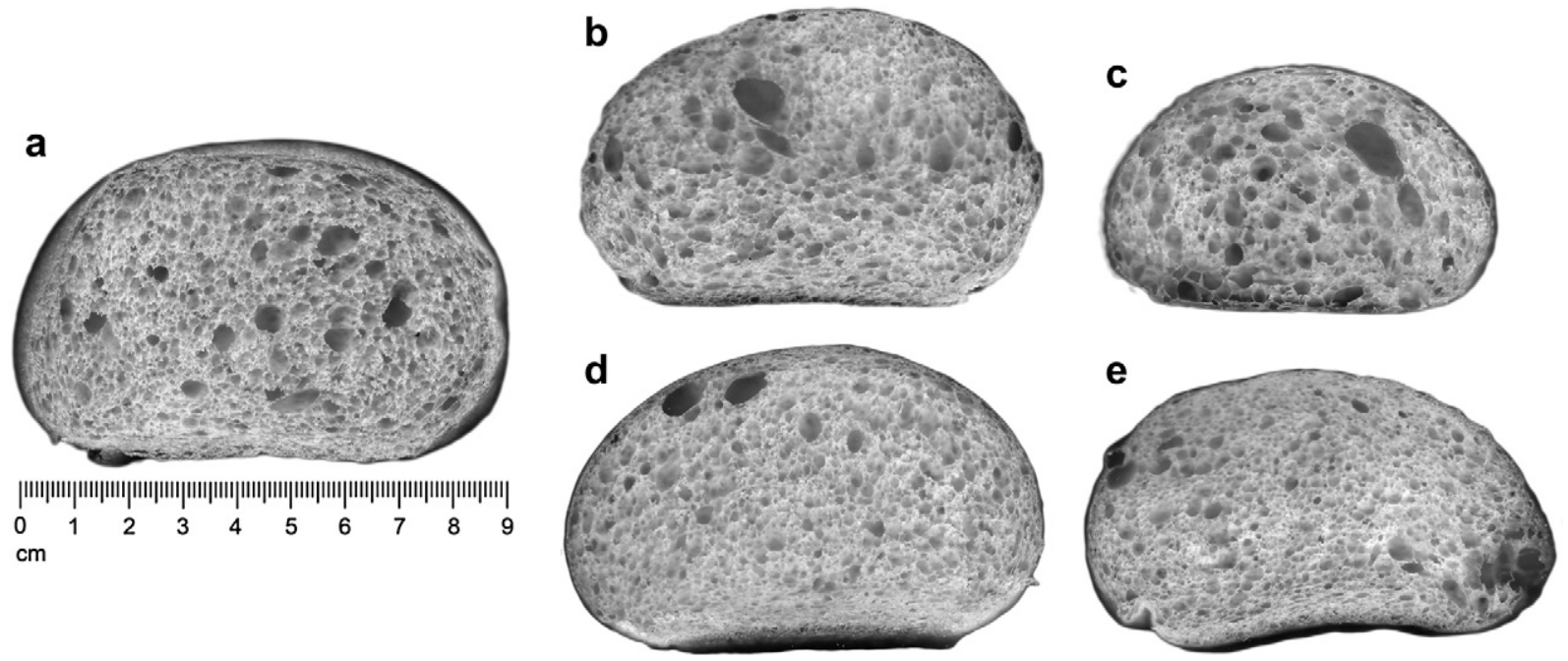

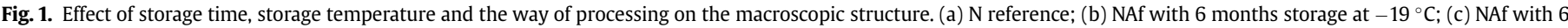
months storage at $-8{ }^{\circ} \mathrm{C}$; (d) NBe with 6 months storage at $-19{ }^{\circ} \mathrm{C}$ and (e) NBe with 6 months storage at $-8{ }^{\circ} \mathrm{C}$.

\subsection{Sensory investigation}

In Fig. 2 the sensory evaluation of NAf and NBe for freshly baked odour (Fig. 2a), springiness (Fig. 2b), as well as off-odour (Fig. 2c) is shown for the storage times 2, 3.5 and 6 months, see also Table 1 for the min and max values. The scores or points refer to high or low appearance of the tested attribute. It was apparent that samples stored at $-8{ }^{\circ} \mathrm{C}$ had an immense difference in most of the tested attributes compared to those stored at -16 and $-19{ }^{\circ} \mathrm{C}$. In chart a can be seen that particularly $\mathrm{NBe}$ at $-8{ }^{\circ} \mathrm{C}$ had very low freshly baked odour with values ranging from 7.4 to 11.0. The highest values were obtained for NAf at $-19{ }^{\circ} \mathrm{C}$ with 81.9 after 2 months. The results for springiness (Fig. 2b) showed that all samples of NAf and NBe had similar values, ranging from 65.9 to 82.6 ; the only sample standing out was NBe stored at $-8{ }^{\circ} \mathrm{C}$. From 54.6 after 2 months, the springiness decreased to 16.6 after 6 months of storage. NBe stored at $-8{ }^{\circ} \mathrm{C}$ had, during all storage times, a strong off-odour, while NAf developed an off-odour particularly between 2 and 3.5 months of storage. Samples stored at -16 and $-19{ }^{\circ} \mathrm{C}$ had almost no off-odour. NAf stored at $-19{ }^{\circ} \mathrm{C}$ at all storage times had the lowest off-odour with scores down to 8.5, compared to the highest value of NBe at $-8{ }^{\circ} \mathrm{C}$ of 83.4 . The other evaluated attributes, which are not shown in the graphs, also differed strongly regarding a storage of $-8{ }^{\circ} \mathrm{C}$ compared to the colder storage temperatures in $\mathrm{NBe}$ and $\mathrm{FiBe}$, for example in off-flavour, moisture, compactness, cracking and elasticity, whereby the samples stored at $-8{ }^{\circ} \mathrm{C}$ that were baked before generally had the most unfavourable quality. Another phenomenon observed was that dough stored at $-8{ }^{\circ} \mathrm{C}$ became darker in colour on the surface, an effect that was still visible after baking. Increased storage time caused bread baked from frozen dough to be less airy, for example, less evenly shaped, less moist and less elastic and to have more offodour and off-flavour; moreover, the compactness increased and the freshly baked odour decreased.

\subsection{Texture and state of water}

Similar to the finding of the compactness in sensory matters, the texture measurements showed similar results; see Fig. 3. Bread without fibre is shown in Fig. 3a and b shows bread with fibre. While the compressive stress of NBe stored at $-16{ }^{\circ} \mathrm{C}$ and $-19{ }^{\circ} \mathrm{C}$ stayed at a similar level throughout the entire storage time with values ranging from 0.00245 to $0.00363 \mathrm{MPa}$. A strong increase of stiffness was detected for NBe at a storage of $-8{ }^{\circ} \mathrm{C}$, particularly after 6 months with $0.11269 \mathrm{MPa}$ (mind the log scale in the charts). For NAf the stiffness increased continuously with storage time, and with a greater increase at warmer storage temperatures, for example at $-8{ }^{\circ} \mathrm{C}$ from $0.00174 \mathrm{MPa}$ after 2 months to $0.01157 \mathrm{MPa}$ after 6 months. That refers also to the volume, seen in chart $\mathrm{d}$ in Fig. 3, which was smaller for Af compared to Be, and therefore the crumb was stiffer. The volume of Be, the bread baked before storage was not measured again after storage since it was considered to be the same approximately. In general, bread with fibre had a slightly stiffer crumb than bread without fibre, but NBe stored at $-8{ }^{\circ} \mathrm{C}$ showed the highest increase in compressive stress.

Fig. $3 c$ shows the results of freezable water $c_{\mathrm{FW}}$ from the DSC measurements of NBe for different storage times at -8 and $-19{ }^{\circ} \mathrm{C}$ compared to $\mathrm{N}$ reference. In the case of $\mathrm{NBe} c_{\mathrm{FW}}$ decreased during storage, particularly at $-8{ }^{\circ} \mathrm{C}$ from initially 16.15 to $12.76 \%$, whereas storage at $-19{ }^{\circ} \mathrm{C}$ caused an additional amount of freezable water of $17.28 \%$ after 2 and $16.5 \%$ after 3.5 months. Mass measurements sustain a finding that NAf stored at $-19{ }^{\circ} \mathrm{C}$ lost more mass during the baking process compared to the baking of the reference. NAf and FiAf, independent of the temperature, had for all times more freezable water than the reference, with the exception FiAf at $-8{ }^{\circ} \mathrm{C}$ and 6 months, which had an amount of 14.17\% freezable water similar to that of the Fi reference with $14.49 \%$. Analogous to NAf, FiAf stored at $-19{ }^{\circ} \mathrm{C}$ gained an extra amount of freezable water, whilst $c_{\mathrm{FW}}$ of FiBe stored at $-8{ }^{\circ} \mathrm{C}$ decreased noticeably after all storage times compared to the reference. Fig. $3 \mathrm{c}$ shows also the heat flow, i.e. the melting of ice after the cooling to $-50{ }^{\circ} \mathrm{C}$ and heating up to $20^{\circ} \mathrm{C}$ in a characteristic thermogram. It compares NBe stored at -19 and $-8{ }^{\circ} \mathrm{C}$ for 6 months to $\mathrm{N}$ reference. The endothermic peak indicates the melting of ice with its maximum at around $-4{ }^{\circ} \mathrm{C}$. Similar to the block chart, marginal increase of the amount of ice can be seen at $-19{ }^{\circ} \mathrm{C}$, while at $-8{ }^{\circ} \mathrm{C}$ the amount decreased slightly.

\subsection{Microstructural investigation}

Some examples of the light micrographs are shown in Fig. 4. The first two images show dough without fibre, the reference (Fig. 4a) and after 6 months storage at $-8{ }^{\circ} \mathrm{C}$ (Fig. $4 \mathrm{~b}$ ). The other 3 images show baked bread, $\mathrm{N}$ reference (Fig. $4 \mathrm{c}$ ), NAf after 6 months storage 

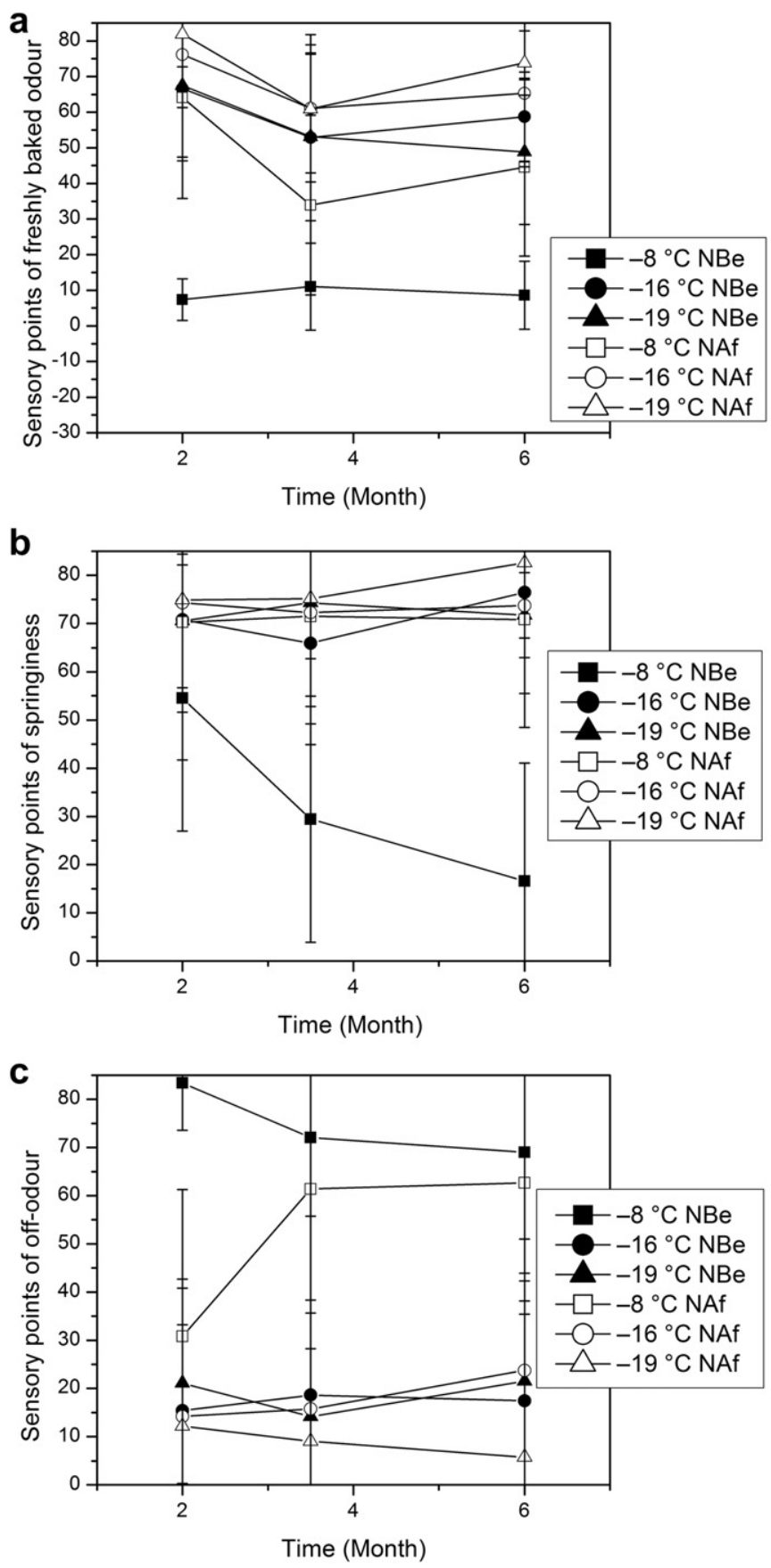

Fig. 2. Effect of storage time and storage temperature on (a) the freshly baked odour, (b) the springiness and (c) the off-odour for NBe and NAf. High scores correspond to high intensity of the attribute.

at $-8{ }^{\circ} \mathrm{C}$ (Fig. $4 \mathrm{~d}$ ) and NBe after 6 months storage at $-8{ }^{\circ} \mathrm{C}$ (Fig. 4e), each at the same magnification (scale bar $=20 \mu \mathrm{m}$ ). The starch granules were stained with iodine and appear bluish, while the gluten phase was stained with light green and appears green, as do the yeast cells. Parts that are black/brown show the fat phase, stained during the fixation of the sample by osmium $\left(\mathrm{OsO}_{4}\right)$. In all images some yeast cells can be seen, which are slightly darker green in colour compared to the gluten phase. When comparing the dough with bread, Fig. 4a and c, it is apparent that the starch granules take up water during baking, which the gluten provides, leading to an increased part of starch and a decreased part of gluten in the final bread, and in total a more compact structure. Moreover, the fat phase undergoes changes.

When the dough reference (Fig. 4a) and the dough after 6 months storage at $-8{ }^{\circ} \mathrm{C}$ (Fig. $4 \mathrm{~b}$ ) are compared, the gluten phase has visibly decreased in volume, as if it has lost part of the water. The gaps between starch and gluten have expanded. For dough that was stored at $-19{ }^{\circ} \mathrm{C}$, the shrinking of the gluten occurred to a much smaller extent, and smaller gaps are visible. No change in shape could be detected for the yeast cells. Optically, they still looked intact.

When looking at NAf with 6 months of storage at $-8{ }^{\circ} \mathrm{C}$ in Fig. $4 \mathrm{~d}$ compared to $\mathrm{N}$ reference in Fig. 4c, gaps are visible, mainly between starch granules without an interface to the gluten. In NAf stored at $-19{ }^{\circ} \mathrm{C}$ the majority of gaps were smaller, and some areas did not show many gaps at all. Bread that was baked before frozen storage had an even more ruptured structure (Fig. 4e). More and bigger gaps appeared compared with NAf. When comparing different temperatures, $-8{ }^{\circ} \mathrm{C}$ storage caused larger and more numerous gaps than storage at -16 and $-19{ }^{\circ} \mathrm{C}$. According to the other measurements, the number and size of gaps seemed to be strongly influenced by the storage temperature and less by the storage time. The images of NBe and FiBe were very similar and no big difference could be observed. When images of lower magnifications were examined, in NAf and FiAf ruptured connections between gas cells became apparent.

\subsection{Statistical results}

In Fig. 5 the bi-plots of a PCA of bread made from frozen dough (Fig. 5a) and bread baked before frozen storage (Fig. 5b) are shown. Samples stored at $-8{ }^{\circ} \mathrm{C}$ are coloured green, $-16^{\circ} \mathrm{C}$ blue and $-19{ }^{\circ} \mathrm{C}$ red, and the references are grey. The physical measurements and the attributes of the sensory analysis are written in black. It can be seen that the samples are grouping according to their temperature, rather than the storage time or the fibre content. Samples stored at -16 and $-19{ }^{\circ} \mathrm{C}$ show similar attributes and are overlying in both plots. Close to the sample names, the sensory attributes as well as the results of the physical investigations that characterise those samples are grouping. NAf and FiAf stored for 6 months at $-8{ }^{\circ} \mathrm{C}$ were, for example, very compact, had high off-odour, off-flavour, and total odour, and had many air bubbles on the surface. Above all, the air bubbles on the surface appeared almost exclusively in NAf and FiAf stored at $-8{ }^{\circ} \mathrm{C}$. Those samples, in addition, showed a discolouration in the form of a darker colour. Samples stored at colder temperatures were more moist and cracking. For NBe and FiBe a crumpled crust was characteristic, in particular for a storage of $-8{ }^{\circ} \mathrm{C}$. The storage of $-8{ }^{\circ} \mathrm{C}$ resulted in similar sensory attributes, independent of whether they were baked before or after storage. When comparing NAf and FiAf (Fig. 5a), it can be seen that NAf is grouping more on the top part, while FiAf tends to be more at the bottom. The samples NBe and FiBe (Fig. 5b) are also grouping according to their fibre content, but they are overlying each other a little more.

\section{Discussion}

\subsection{Impact of temperature}

As described in the results, most differences were examined depended on the storage temperature. That was already apparent when only the volume of bread baked from frozen dough was compared. One reason is that yeast is less viable after frozen storage, particularly at warmer temperatures like $-8{ }^{\circ} \mathrm{C}$ (Mazur, 1970). At these temperatures recrystallisation of ice crystals occurs in which ice crystals change in number, size and shape 

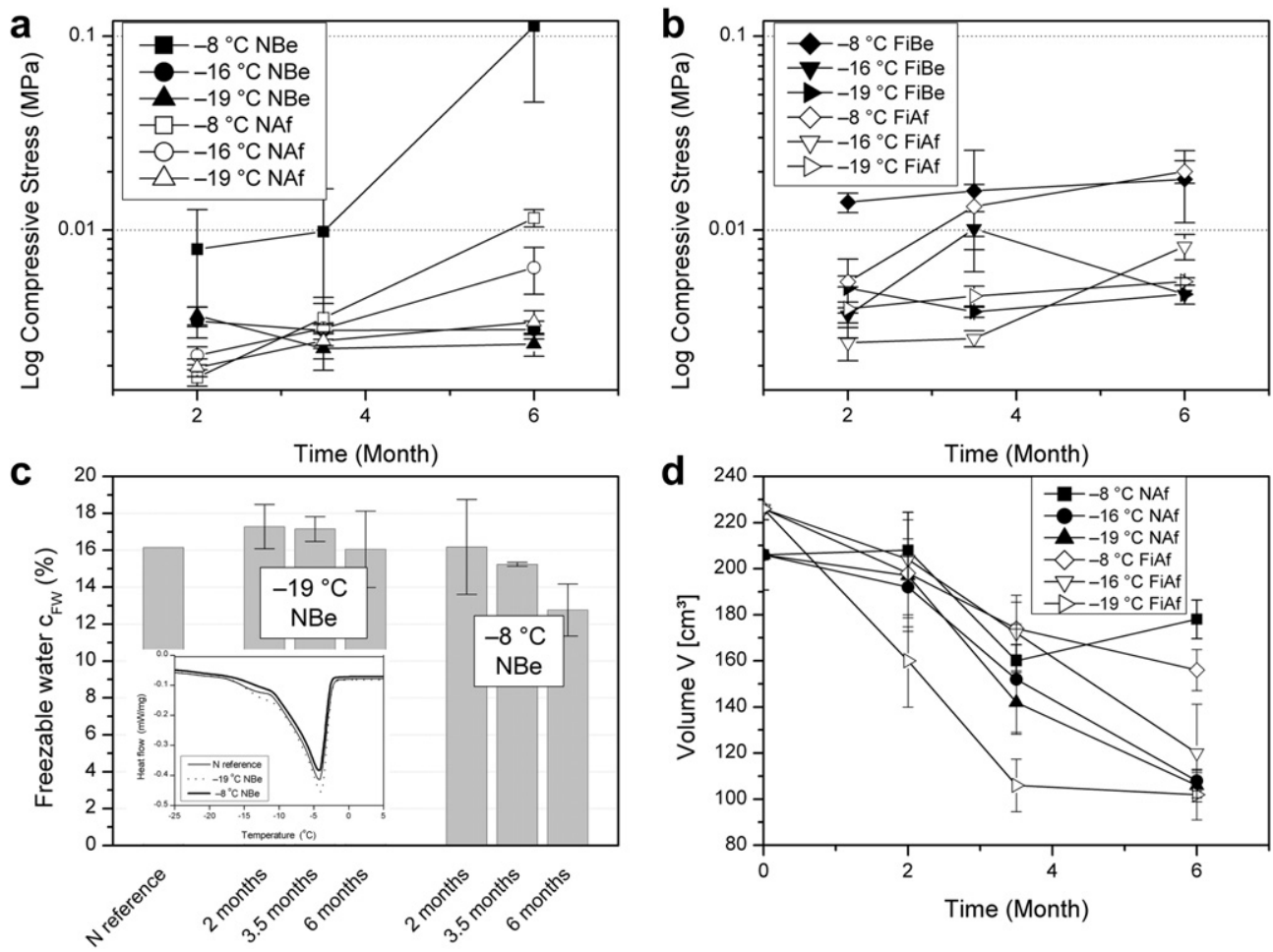

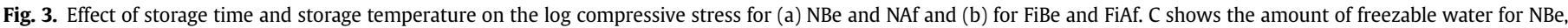
including the heat flow of NBe stored for 6 months at -19 and $-8{ }^{\circ} \mathrm{C}$ compared to $\mathrm{N}$ reference. In chart $\mathrm{d}$ the bread volume of NAf and FiAf over time is plotted.

(Petzold and Aguilera, 2009). This results in bigger ice crystals, which leads to destruction of the structure and possibly also the yeast cells. At constant temperatures small crystals, which have higher vapour pressure compared to large crystals, tend to grow and fuse into bigger crystals, a phenomenon known as Ostwald ripening. This phenomenon is rather small; the main damage is caused as a result of temperature fluctuations (Petzold and Aguilera, 2009). As the temperature increases, some ice crystals, particularly smaller ones, melt, thus increasing the total amount of unfrozen water. When the temperature decreases again, no further nucleation will take place, and the free water will refreeze on the surface of already existing ice crystals (Petzold and Aguilera, 2009). Recrystallisation of ice crystals is very temperature dependent; colder temperatures slow down the process, while warmer temperatures facilitate it (Roos, 1995). Temperatures can also show great differences, depending on where the product is placed in the freezer. If samples lie closer to the fan, they are likely to loose more moisture, since they are exposed to higher temperature changes. The results of the samples stored at -16 and $-19{ }^{\circ} \mathrm{C}$ did not differ a lot. The reason may be that the mean temperature in the freezer of $-19{ }^{\circ} \mathrm{C}$ had in average only $3{ }^{\circ} \mathrm{C}$ difference to the mean temperature of $-16{ }^{\circ} \mathrm{C}$. As the colour change of dough stored at $-8{ }^{\circ} \mathrm{C}$ indicates, enzymes can even be active at temperatures of $-8{ }^{\circ} \mathrm{C}$ (Timm and Herrmann, 1996). A possible cause of the offodour (Fig. 2c) and off-flavour could therefore also have been the activity of enzymes, for example, lipases making fat rancid. However, further studies are necessary to investigate the phenomenon. Fig. 2c shows that even NAf stored at $-19{ }^{\circ} \mathrm{C}$ was evaluated with less off-odour over time, but that effect might be due to the fact that the difference from the other samples became higher, and the assessors sensed this sample as very good in relation to the others.

Several authors (Havet et al., 2000; Inoue and Bushuk, 1992; Kenny et al., 1999; Leray et al., 2010) report that the rheological properties of dough undergo great changes caused by the initial freezing. Some authors (Kenny et al., 1999; Leray et al., 2010) also report that the dough rheology does not change during frozen storage, independent of the storage temperature. But mainly colder temperatures like $-19{ }^{\circ} \mathrm{C}$ and storage times shorter than 3 months were tested. However, Inoue and Bushuk stored dough up to 10 weeks at $-19{ }^{\circ} \mathrm{C}$ and found a decrease in maximum extensigraph resistance and an increase in extensibility (consistent with dough weakening). For temperatures at $-8{ }^{\circ} \mathrm{C}$ the changes might even be higher. In our tests, for NAf stored at $-8{ }^{\circ} \mathrm{C}$ (Fig. 1c), the gas cells were bigger and fewer in number compared with the cooler storage temperatures. A possible change in rheological properties causing different expansion behaviour of gas cells during proofing could be the reason.

In $\mathrm{NBe}$ and FiBe the different storage temperatures might have caused different rates of retrogradation or the crystallisation of the starch during frozen storage. It is known (Cauvain, 1998; Klingler, 1995; Walstra, 2003) that retrogradation is fastest around $4{ }^{\circ} \mathrm{C}$ in baked bread. Out of the tested temperatures $-8{ }^{\circ} \mathrm{C}$ was closest and therefore also had the highest rate of retrogradation. The texture measurements also showed that bread stored at $-8{ }^{\circ} \mathrm{C}$ was harder at all times than bread stored at colder temperatures. Although there might not be a direct "cause-and-effect relationship" (Gray and Bemiller, 2003) between retrogradation/crystallisation and the crumb firmness, it usually occurs simultaneously and indicates the staling of bread.

In microscopic scale the gaps next to the starch granules (Fig. 4e) indicate a recrystallisation, whereby water has leached from the granules. DSC measurements show that bread stored at $-19{ }^{\circ} \mathrm{C}$ gained an extra amount of freezable water, while it had less freezable water at $-8{ }^{\circ} \mathrm{C}$. That could indicate that gelatinised starch in bread at $-19{ }^{\circ} \mathrm{C}$ retrogradates, resulting in higher amounts of freezable water. This assumption is supported by the micrographs that showed gaps in all frozen stored bread samples. At warmer 

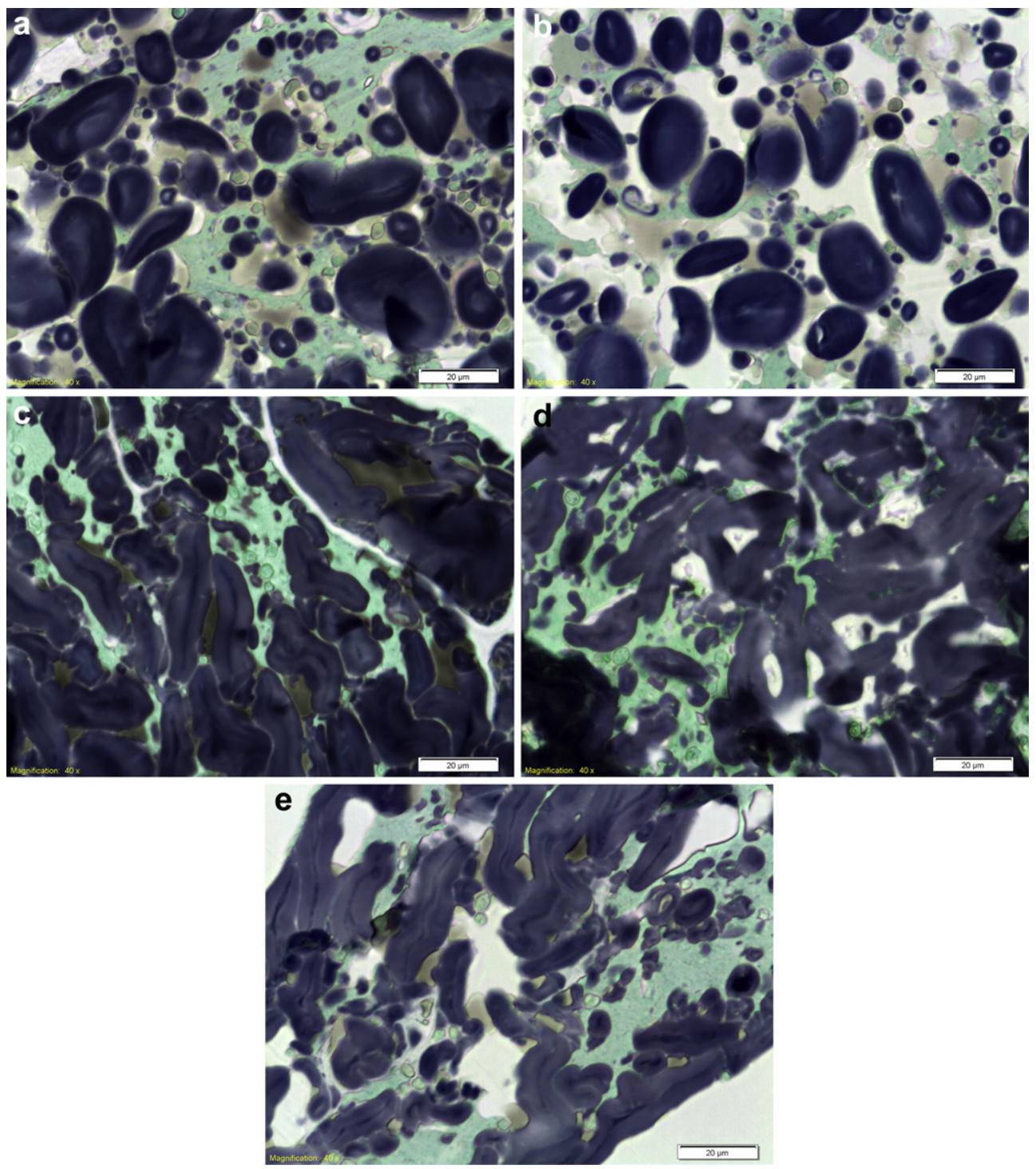

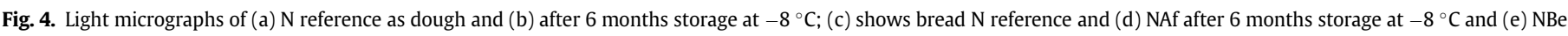

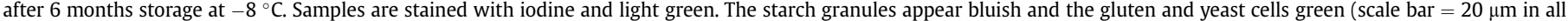
images).

temperatures retrogradation takes place to an even higher extent (Klingler, 1995); a possible explanation for the decreased amount of freezable water is a drying of the bread, which is faster at those temperatures, leading to lower water content in total.

\subsection{Impact of storage time}

The PCA plots in Fig. 5 show that main impact was caused by the storage temperature. That is also due to the outstanding temperature $-8{ }^{\circ} \mathrm{C}$; when excluding this temperature, the highest influence is caused by the storage time. As described in the results, the volume of NAf and FiAf changed significantly compared with the reference, depending on the storage time. Accordingly, the stiffness, expressed as compressive stress (Fig. 3a, b) also increased. Recrystallisation of ice, as it is described in Section 4.1, is very much time dependent, and accelerates when temperature fluctuations occur. Over time, water from the gluten matrix separates, resulting in free water that subsequently crystallises. When more and more water separates from the gluten and crystallises on the already existing ice crystals, it causes even further structural damage. Free water or ice is more likely to move around in the sample. This assumption conforms with the findings of Esselink et al. (2003), who mapped the water density of dough slices with magnetic resonance imaging, with the result that the density of water increases at the periphery of the sample during storage time and, contrary to the assumptions of other authors, this water does not return to its original state after thawing. Gas cells in dough, independent of whether they originated before or after proofing, seem to have a special effect. Baier-Schenk et al. (2005), for example, found with in situ observations with confocal laser scanning microscopy (CLSM), that ice formation preferentially occurs at the gas pore interface, there leading to larger ice crystals. That might be due to irregularities or the presence of nucleation sites that promote heterogeneous nucleation. Chen et al. (2012) made DSC measurements and found a major and a minor endothermic peak, whereby they attributed the major one to the ice in bigger pores (gas cells) and the minor one to the ice in smaller pores within the gluten starch matrix. Esselink et al. (2003) concluded that during storage time the void fraction is filled with ice crystals, leading to local high water densities after thawing. Taking the assumption 

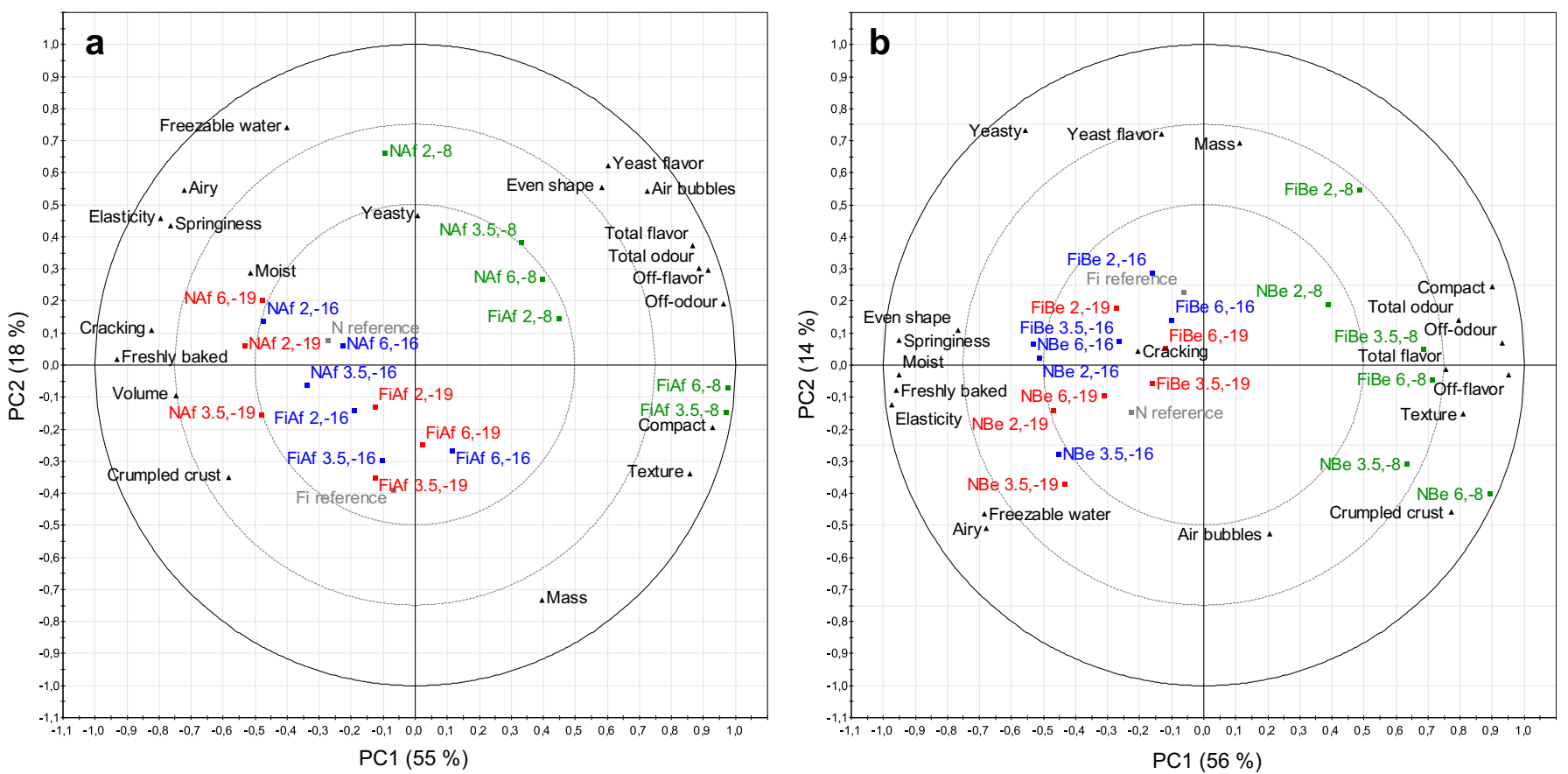

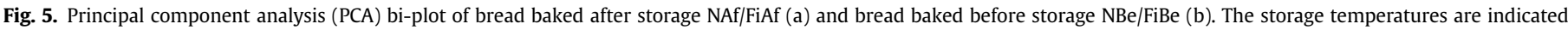
with $-8,-16$ and -19 and the storage times with $2,3.5$ and 6 .

that the gluten dehydrates during frozen storage, that causes the gluten phase to have a higher concentration, leading to higher osmotic pressure for the yeast cells, which therefore equilibrate by losing water. Thus the yeast cells' solutes concentrate, causing injuries to the cells, which results in lower loaf volume. Also possible is the theory that yeast cell leachates contain glutathione (Wolt and D'Appolonia, 1984), leading to different characteristics of the dough rheology.

In frozen bread the effects are expected to be similar. However, the amount of freezable water can change due to freezing damage, such as starch retrogradation and gluten disruption. As well, a part of the freezable water migrates outward and forms ice crystals below the crust and on the outer bread surface. This loss of freezable water causes drying of the frozen crumb, which becomes more significant upon longer frozen storage (Fig. 3c).

\subsection{Effect of additional fibre}

In the PCA bi-plots in Fig. 5 bread with and without fibre is grouping slightly, as described in Section 3 . That is partly a result of different initial mass, since bread without fibre was lighter than bread with fibre. Bread with fibre a more compact crumb structure than bread without fibre had in general. The results of the texture measurements correspond to the sensory measurements. In the attributes airiness and compactness the same tendency was observed as the measurements with the texture analyser. Another aspect that needs to be taken into account is that fibre has been added to the dough in the form of whole wheat kernels, rather than as a fine distribution. The latter would have caused a stronger effect.

\subsection{Freezing raw dough vs. baked bread}

When looking at the temperatures -16 and $-19^{\circ} \mathrm{C}$, the physical results were rather similar between bread baked from frozen dough and bread baked before storage. However, big differences were detected in the sensory evaluation, for example, that bread baked from frozen dough was moister, airier and springier, and had a stronger freshly baked odour than bread baked before storage.

Bread baked before storage, on the other hand, always had a crumpled crust and off-odour and off-flavour. For bread baked from frozen dough, the volume decreased the longer the storage and the warmer the temperature, and therefore the stiffness of the crumb continuously increased, but in total the sensory attributes gave preferable results in contrast to bread baked before storage. Similar conclusions were stated by Fik and Surówka (2002) who found that part-baked bread had much better sensory quality compared to frozen stored fully-baked breads. More emphasis should be put on the sensory results, since they are the determining factor for the consumer, which means that bread baked from frozen dough should be preferred.

\subsection{The impact of water}

Water plays a complex role in the freezing of dough and bread. Frozen goods are not in a state of equilibrium. There is a continuous movement of water and changes in the shapes and sizes of ice crystals. Mainly due to temperature fluctuation, water originating from the gluten, the starch phase or free water crystallises at the already existing ice crystals, leading to a continuously increasing size of ice crystals. The DSC measurements also showed that the amount of freezable water partly increases (Fig. 3c), which means that parts of the water that were bound to the gluten or the starch became free to move within the sample. When the free water crystallises, the surrounding solution concentrates and the yeast cells react by losing water due to the osmotic pressure, with adverse effects for the cells. In baked bread the gelatinised starch partly retrogradates, thereby also losing water and supporting the growth of ice crystals. Those crystals physically damage the structure of the dough. The resulting gaps that were created during frozen storage were seen in the micrographs (Fig. 4d). Bread stored at warmer temperatures, primarily FiBe at $-8^{\circ} \mathrm{C}$, had less freezable 
water after storage compared with the respective reference. A drying of the sample may be the explanation for this phenomenon. Also Bárcenas and Resell (2006) found that the moisture content of baked bread decreased with time of frozen storage. In general the concentration effects due to recrystallisation of ice induce accelerated chemical reactions, making dough and bread age faster.

\section{Conclusions}

This study shows that bread has favourable sensorial characteristics when it is stored as dough with subsequent baking after frozen storage. Although volume decreases and therefore the compactness of the crumb increases after frozen storage, more attention should be paid to the sensory characteristics, such as freshly baked odour, since this is the way the consumer judges the product. Out of the tested storage temperatures $-19{ }^{\circ} \mathrm{C}$ gave the best results, whereby $-16{ }^{\circ} \mathrm{C}$ gave comparable results and $-8{ }^{\circ} \mathrm{C}$ differed strongly in all measurements from the other two colder temperatures. It was hypothesised that the water movement was a lot higher at $-8{ }^{\circ} \mathrm{C}$ compared with -16 and $-19{ }^{\circ} \mathrm{C}$ and that enzymes were still active at this temperature, causing adverse effects resulting in abnormal colouring and off-odour. Extended storage time did have a strong, unfavourable impact, particularly at warmer temperatures, like $-8{ }^{\circ} \mathrm{C}$. For -16 and $-19{ }^{\circ} \mathrm{C}$ the effects were less pronounced, but still perceptible. Despite some parts of the mechanisms occurring in frozen dough and bread remaining unknown, it has been shown that the large number of different kinds of analysis and the interdisciplinary work has led to a holistic view and a better understanding of the freezing of dough and bread.

\section{Acknowledgements}

This study has been carried out with the financial support of the Swedish Board of Agriculture and the companies Lantmännen, Sveba Dahlen, Fazer, Jästbolaget, Ewalco, JBT FoodTech, Norlander Zeelandia and Dafgård.

\section{References}

American Association of Cereal Chemists, 2001. Approved Methods of the AACC Method 10-05, Guidelines for Measurement of Volume by Rapeseed Displacement; Method 74-09, Measurement of Bread Firmness by Universal Testing Machine. AACC, St. Paul, MN.

Baier-Schenk, A., Handschin, S., von Schönau, M., Bittermann, A.G., Bächi, T., CondePetit, B., 2005. In situ observation of the freezing process in wheat dough by confocal laser scanning microscopy (CLSM): formation of ice and changes in the gluten network. Journal of Cereal Science 42 (2), 255-260.

Bárcenas, M.E., Haros, M., Rosell, C.M., 2003. An approach to studying the effect of different bread improvers on the staling of pre-baked frozen bread. European Food Research and Technology 218 (1), 56-61.

Bárcenas, M.E., Resell, C.M., 2006. Effect of frozen storage time on the bread crumb and aging of par-baked bread. Food Chemistry 95 (3), 438-445.
Cauvain, S.P., 1998. Improving the control of staling in frozen bakery products. Trends in Food Science and Technology 9 (2), 56-61.

Chen, G., Jansson, H., Lustrup, K.F., Swenson, J., 2012. Formation and distribution of ice upon freezing of different formulations of wheat bread. Journal of Cereal Science 55 (3), 279-284.

Esselink, E.F.J., van Aalst, H., Maliepaard, M., van Duynhoven, J.P.M., 2003. Longterm storage effect in frozen dough by spectroscopy and microscopy. Cereal Chemistry 80 (4), 396-403.

Fik, M., Surówka, K., 2002. Effect of prebaking and frozen storage on the sensory quality and instrumental texture of bread. Journal of the Science of Food and Agriculture 82 (11), 1268-1275.

Filipović, J., Popov, S., Filipović, N., 2008. The behavior of different fibers at bread dough freezing. Chemical Industry and Chemical Engineering Quarterly 14 (4), 257-259.

Gray, J.A., Bemiller, J.N., 2003. Bread staling: molecular basis and control. Comprehensive Reviews in Food Science and Food Safety 2 (1), 1-21.

Hamdami, N., Pham, Q.T., Le-Bail, A., Monteau, J.-Y., 2007. Two-stage freezing of part baked breads: application and optimization. Journal of Food Engineering 82 (4), 418-426.

Havet, M., Mankai, M., Le Bail, A., 2000. Influence of the freezing condition on the baking performances of French frozen dough. Journal of Food Engineering 45 (3), 139-145.

Hsu, K., Hoseney, R.C., Seib, P.A., 1979. Frozen dough II. Effects of freezing and storing conditions on the stability of frozen doughs. Cereal Chemistry 68 (4), 423-428.

Inoue, Y., Bushuk, W., 1992. Studies on frozen doughs. II. Flour quality requirements for bread production from frozen dough. Cereal Chemistry 69 (4), 423-428.

Kenny, S., Wehrle, K., Dennehy, T., Arendt, E.K., 1999. Correlations between empirical and fundamental rheology measurements and baking performance of frozen bread dough. Cereal Chemistry 76 (3), 421-425.

Klingler, R.W., 1995. Grundlagen der Getreidetechnologie, first ed. Behr's Verlag, Hamburg.

Leray, G., Oliete, B., Mezaize, S., Chevallier, S., de Lamballerie, M., 2010. Effects of freezing and frozen storage conditions on the rheological properties of different formulations of non-yeasted wheat and gluten-free bread dough. Journal of Food Engineering 100 (1), 70-76.

Lucas, T., Le Ray, D., Davenel, A., 2005. Chilling and freezing of part-baked bread. Part I: an MRI signal analysis. Journal of Food Engineering 70 (2), 139-149.

Mandala, I., Polaki, A., Yanniotis, S., 2009. Influence of frozen storage on bread enriched with different ingredients. Journal of Food Engineering 92 (2), 137 145.

Mazur, P., 1970. Cryobiology: the freezing of biological systems. Science 168 (3934), 939-949.

Neyreneuf, O., Delpuech, D., 1993. Freezing experiments on yeasted dough slabs. Effects of cryogenic temperatures on the baking performance. Cereal Chemistry 70 (1), 109-111.

Petzold, G., Aguilera, J.M., 2009. Ice morphology: fundamentals and technological applications in foods. Food Biophysics 4 (4), 378-396.

Polaki, A., Xasapis, P., Fasseas, C., Yanniotis, S., Mandala, I., 2010. Fiber and hydrocolloid content affect the microstructural and sensory characteristics of fresh and frozen stored bread. Journal of Food Engineering 97 (1), 1-7.

Roos, Y.H., 1995. Phase Transitions in Foods. Academic Press, London.

Seetharaman, K., McDonough, C.M., Waniska, R.D., Rooney, L.W., 1997. Microstructure of wheat flour tortillas: effects of soluble and insoluble fibres. Food Science and Technology International 3 (3), 181-188.

Selomulyo, V.O., Zhou, W., 2007. Frozen bread dough: effects of freezing storage and dough improvers. Journal of Cereal Science 45 (1), 1-17.

Timm, F., Herrmann, K., 1996. Tiefgefrorene Lebensmittel, second ed. Behr's Verlag, Hamburg.

Walstra, P., 2003. Physical Chemistry of Foods. Marcel Dekker, New York.

Wolt, M., D’Appolonia, B., 1984. Factors involved in the stability of frozen dough. I. The influence of yeast reducing compounds on frozen-dough stability. Cereal Chemistry 61 (3), 213-221.

Zounis, S., Quail, K.J., Wootton, M., Dickson, M.R., 2002. Effect of final dough temperature on the microstructure of frozen bread dough. Journal of Cereal Science 36 (2), 135-146. 